\title{
THE ROLE OF ZAKAT IN OVERCOMING INFLATION AND UNEMPLOYMENT: REVISITING THE TRADE-OFF THEORY
}

\author{
Mohammad Syafi Antonio* \\ Mohammad Mahbubi Ali** \\ Jebel Firdaus***
}

\begin{abstract}
The present study aims to examine the role of zakat in addressing unemployment and inflation, while also revisiting A.W. Phillips' trade-off theory. The study adopts a qualitative methodology, using library research to critically analyse how zakat could address unemployment and inflation. The study argues that the optimal application of zakat could overcome the issue of unemployment while maintaining price stability. This is true since zakat can be distributed in two forms: consumptive and productive. Therefore, an increase in aggregate demand will always be followed by a rise in aggregate supply; the distribution of zakat in the consumptive form will increase aggregate demand, while the distribution of zakat for a productive purpose will increase aggregate supply. An increase in aggregate demand would in turn increase production, thus absorbing more labour as a result. This is where zakat addresses unemployment. On the other hand, a rise in aggregate demand will initially inflate the aggregate price. However, since the increase in aggregate demand is simultaneously followed by an increase in aggregate supply due to the distribution of zakat in its productive form, the price remains stable. Aggregate demand and aggregate supply cross at an equilibrium point. More importantly, the price is stable while the quantity of production is at its highest level. The findings of the study serve as a reference point for regulators formulating fiscal policy embedded in the zakat system.
\end{abstract}

Keywords: Zakat, Inflation, Unemployment, Trade-off, A.W. Phillips, Fiscal Policy

\section{Introduction}

Inflation and unemployment have become major macro-economic issues in many countries for two reasons. ${ }^{1}$ Firstly, inflation and unemployment are the two most common economic indicators of how well a country is doing. Secondly, inflation and unemployment bring about an adverse impact on both developing and developed countries. 
Many macro-economic studies explain how government policies address both inflation and unemployment. Many governments and policymakers have introduced policies, strategies, and models addressing both issues, and which conclude that inflation and unemployment cannot be overcome simultaneously. If the focus of a government policy is price stability, unemployment rates will increase and vice versa. This is known as the trade-off theory, introduced by A.W. Phillips in $1958 .^{2}$ In his article, 'The Relation between Unemployment and the Rate of Change of Money Wage Rates in the United Kingdom, 18611957,' Phillips concluded: "when the demand for a commodity or service is high relative to the supply of it we expect the price to rise, the rate of rise being greater the greater the excess demand. Conversely, when the demand is low relatively to the supply we expect the price to fall, the rate of fall being greater the greater the deficiency of demand." ${ }^{3}$ However, Phillips' theory began to collapse when many developed countries in the 1970s and Asian countries in 1997 suffered from both high unemployment and inflation due to financial crisis. ${ }^{4}$ The question thus brought to the fore was: if Phillips' theory collapses when inflation and unemployment are concomitantly moving in a negative direction, is there any instrument that could address both inflation and unemployment simultaneously?

This article argues that zakat, the third pillar of Islam, can play a significant role in addressing both inflation and unemployment simultaneously. The potential size of annual zakat collections worldwide is enormous, being estimated at between US\$200 billion and US\$1 trillion. ${ }^{5}$ The World Bank and the Islamic Research and Training Institute (IRTI) of the Islamic Development Bank (IDB) estimate that the global potential of zakat is US\$550-600 billion per year. Nevetheless, official zakat institutions worldwide currently only collect US\$10-15 billion every year. ${ }^{6}$ As a sub-system of Islamic teachings, however, the optimal application of zakat could resolve the issue of unemployment while maintaining price stability. This is particularly true since the nature of zakat distribution addresses not just consumption, but also production. Consequently, an increase in aggregate demand will always be followed by an increase in aggregate supply; thus an equilibrium point is maintained.

Many studies have examined the impact of zakat on economic growth, ${ }^{7}$ while others explore the role of zakat in poverty alleviation. ${ }^{8}$ By contrast, a cursory review of the existing literature demonstrates that, to the best of the authors' knowledge, nothing has been written about the role of zakat in addressing both inflation and unemployment. This paper, therefore, aims to fill that gap in the existing literature. Following this brief introduction, the paper is organised as follows. After a review of the concepts of zakat, inflation, and unemployment, the paper examines past studies relevant to the subject in question, before 
proceeding to delve into how zakat can impact both inflation and unemployment. This final part of the paper will also shed critical light on how the concept of zakat revises Phillips' theory. The concluding part of the paper presents a set of policy recommendations.

\section{Literature Review}

\section{Zakat}

Zakat comes from the Arabic word zaka, meaning 'to grow, increase, and purify.' Ibn Taymiyyah said: "the soul of the person who pays zakat becomes purified from greed and avarice, and the blessings in his wealth increase." Legally, zakat refers to the transfer of a portion of wealth to one or more rightful recipients (asnaf), as outlined in the Qur'an. ${ }^{10}$ As the third pillar of Islam, zakat is obligatory on every Muslim who owns assets of a minimum amount set by shariah (the nisab) and that is possessed for a year (haul).

The distribution of zakat is restricted to eight categories of beneficiary: ${ }^{12}$ the poor (faqir), the needy (miskin), zakat personnel (amil), people whose hearts are inclined towards Islam (mu'allafah qulub), those in bondage ( $f$ alriqab), indebted people (gharimin), wayfarers (ibn al-sabil), and those in the path of Allah ( $f$ sabilillah). The sources of wealth subject to zakat include: livestock, gold, silver, agricultural products, animal products, minerals, business inventories, capital goods, and the earnings of workers and professionals. The conditions for nisab, haul, and the rates of zakat vary across these categories. For instance, the zakat on agricultural products need not necessarily meet the condition of haul as it is levied immediately upon harvest. The rate also varies, being 10 per cent for crops watered naturally and 5 per cent for those watered artificially. Meanwhile, the rate of zakat on business inventories is set at 2.5 per cent of net asset value during the prevailing year.

Apart from its spiritual and moral dimensions, zakat is part of the socioeconomic system of Islam. Zakat stimulates the economy by allowing the poor (faqir) and needy (miskin) to become economically productive. By instituting zakat, Islam prevents the widening of the gap between rich and poor, allowing a certain portion of the income of the wealthy to be channeled to the havenots. Zakat can also be used for various additional socio-economic purposes, like education, healthcare, social welfare, and promoting the productivity of the poor. Therefore, from an economic point of view, zakat serves as an effective measure in the socio-economic system of Islam. 


\section{Inflation}

Inflation refers to a substantial and consistent increase in the general price level of goods and services over the long term. ${ }^{13}$ In other words, inflation is a process of continuous decrease in the value of currency. It is a process, not merely a high or low price level at a point in time. A high price level does not necessarily indicate inflation. It can only be considered inflation if there is a persistent increase in the general price level over time. ${ }^{14}$

In conventional economics, two diametrically opposed views exist concerning the sources of inflation, the Keynesian and the Monetarist. The Keynesian school recognises three types of inflation: demand-pull inflation, cost-push inflation, and expected inflation. ${ }^{15}$ Demand-pull inflation occurs when aggregate demand for goods and services exceeds aggregate supply. Cost-push inflation is an increase in aggregate price level due to a decline in aggregate supply, thus increasing production costs. Theoretically, if productivity decreases, aggregate supply drops and price levels increase. ${ }^{16}$ Expected inflation is an aggregate increase in price level in tune with expectations about the overall price of goods and services over a certain period. ${ }^{17}$ In contrast to these three categories, the Monetarist school acknowledges only one determining factor in inflation: excessive money supply. Therefore, a government can control inflation either by easing or tightening money policy.

In Islam, inflation is defined as an increase in general price levels due to excessive money supply. ${ }^{18}$ Al-Maqrizi (766-845AH/1364-1441CE), a Muslim economist who was a disciple of Ibn Khaldun, divides the root causes of inflation into two: natural inflation and human error inflation. ${ }^{19}$ Natural inflation results from natural factors a government cannot control. It is caused by either an increase in aggregate demand or a decrease in aggregate supply. An increase in aggregate demand for goods and services pulls up demand for production, which in turn causes an increase in production costs/prices. At this juncture, in full employment situations, inflation occurs due to an increase in aggregate demand. In a conventional economy, this is called demand-pull inflation. Similarly, a drop in average production levels would also push up price levels due to an increase in aggregate demand. In a conventional economy, this is called costpush inflation. In a nutshell, therefore, natural inflation originates from either excessive money supply or a decrease in production due to natural disasters, wars, or embargoes. ${ }^{20}$ Apart from natural factors, inflation can also be triggered by human factors, such as corruption and bad administration, excessive taxes, and excessive seignorage. ${ }^{21}$ 


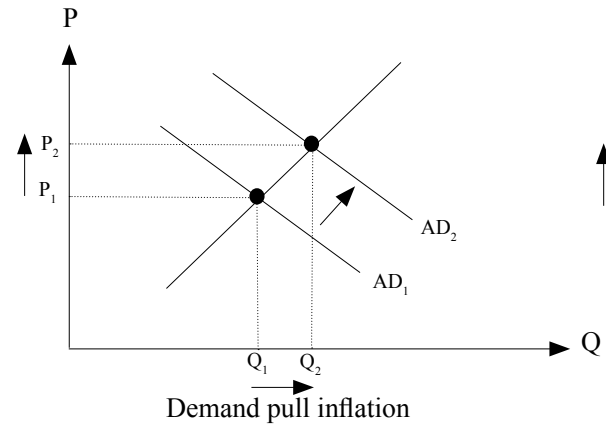

Figure 1: Types of Inflation

Source: Karim, 2004

\section{Unemployment}

The word 'unemployment' did not come into use until the end of the nineteenth century; according to the Oxford English Dictionary, the term was first used in 1895. Etymologically, 'unemployment' signifies a state of involuntary idleness, where a person remains jobless for various reasons over a certain period. The International Labour Organisation passed a resolution in 1982 that an individual is deemed unemployed if he/she is jobless for a particular period, despite being available for work and actively seeking a job.

Generally, there are three forms of unemployment: ${ }^{22}$

1. Frictional unemployment, or when workforces are temporarily unemployed or not working. This may be due to persistent movement, whether from one area to another or one job to another, or due to different stages in life cycle.

2. Structural unemployment, or a situation where there is a mismatch between demand and supply for a workforce. This mismatch might emerge when demand for certain types of labour either increases or diminishes. While structural unemployment is also a form of frictional unemployment, it normally lasts longer.

3. Cyclical unemployment, which occurs due to a decrease in demand for goods and services, causing a drop in production, often resulting from economic recession. In response, employers might reduce their workforce. 


\section{The Phillips Theory}

Inflation and unemployment are major economic problems in both developing and developed countries. Theoretically, the two problems cannot be resolved concurrently as pushing a country's economy into full employment will invoke inflation. This is because economic development requires investment in infrastructure projects; government spending on investment increases demand for goods and services, which in turn increases production and, ultimately, employment. This again causes an increase in demand for goods and services, inflating general price levels.

On one level, governments can increase interest rates to reduce inflation. When interest rates rise, investors are reluctant to invest their money in the real sector, preferring to place it in financial institutions. As a result, money circulation reduces, aggregate demand falls, the economy slumps, and the price of goods and services decreases. Yet, unemployment rates will increase under these circumstances because employers reduce their workforces due to drops in aggregate demand. This is what economists call a trade-off.

As mentioned, the trade-off theory linking inflation with unemployment originated with British economist, A.W. Phillips. His study examined the relationship between unemployment rates and inflation in England between 1861 and 1957. The study found a negative relationship between unemployment and inflation; if inflation was low, unemployment was high, and vice versa. ${ }^{23}$ This theory was further examined and substantiated by Samuelson and Solow, using empirical date from the United States covering the period 1900 to $1960 .{ }^{24}$ The Phillips theory is illustrated by the following curve, known as the Phillips curve:

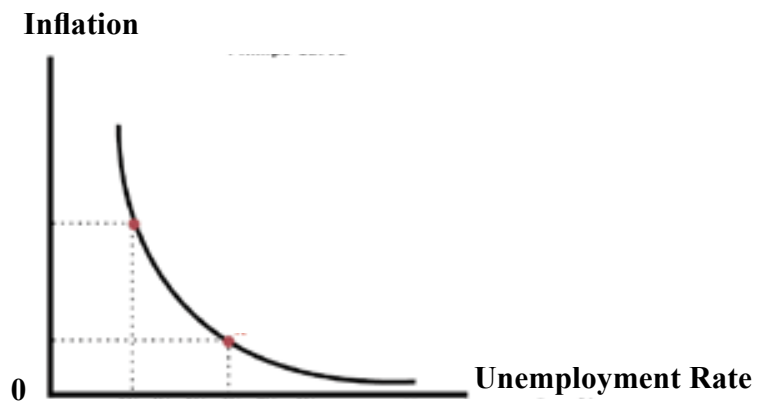

Figure 2: Phillips Curve

Source: Phillips, 1958 
The horizontal line represents the workforce unemployment rate, the vertical line inflation. With low unemployment, inflation is high. If inflation is low, unemployment is high. ${ }^{25}$

\section{Previous Studies}

A cursory review of the available literature reveals several studies examining the impact of zakat on economic growth, public welfare, and poverty alleviation. ${ }^{26}$ For example, Sarea explored zakat as an indicator of economic growth, arguing that it can contribute to economic development in terms of poverty alleviation and reduction of both unemployment and inflation. ${ }^{27}$ Furthermore, Mahat and Warokka, using macro-economic data from 19 Muslim countries produced between 2004 and 2010, concluded that zakat is a powerful, implementable economic growth policy. ${ }^{28}$

Yusoff, examining panel data from the 14 states in Malaysia, discovered that both zakat and education play a significant role in GDP (Gross Domestic Product) ${ }^{29}$ In a similar vein, Azam et al. discovered that zakat has a positive impact on economic development in Pakistan. In particular, micro evidence suggests that zakat impacts positively and significantly on household welfare, while macro analysis indicates a positive effect on economic growth. ${ }^{30}$ In contrast, Khasandy et al. found that zakat distribution in Indonesia did not contribute significantly to economic growth or social welfare. ${ }^{31}$

Other studies have examined the impact of zakat on poverty alleviation. ${ }^{32}$ For instance, Hassan and Ashraf argue that both theoretical and empirical evidence substantiates zakat's role in poverty alleviation. Theoretically, the object of zakat is to facilitate socio-economic justice, "so that the wealth may not (merely) make a circuit between the wealthy among you." ${ }^{33}$ In this context, poverty alleviation is the main priority of zakat, with the poor and needy being the most important category of eligible recipient (asnaf). ${ }^{34}$ It is not permissible, for example, to distribute zakat funds to the army while the poor and needy require food, shelter, and other necessities. ${ }^{35}$ Metwally argued that zakat distribution increases purchasing power and consumption among the poor. ${ }^{36}$

Empirically, Abdullah et al. used the BNDI (Basic Need Deficiency Index) to argue that zakat distribution can reduce poverty and inequality in Pakistan. ${ }^{37}$ In a similar vein, Raimi found that zakat and waqf models serve as sustainable social safety nets in Nigeria, ${ }^{38}$ with Hashem discovering a similar pattern in Egypt. ${ }^{39}$ Sheikh and Ismail, meanwhile, concluded that zakat is supportive of sustainable goals (SDGs), including alleviation of: poverty, hunger, ill health, education inequality, unemployment, poor economic growth, and income inequality ${ }^{40} \mathrm{~A}$ study by Noor also confirmed that zakat is a powerful tool for attaining SDGs ${ }^{41}$ 
Although these studies cover the role of zakat in economic growth, poverty alleviation, financial inclusion, and the attainment of SDGs, to the best of the current authors' knowledge, no study examines the role of zakat in addressing inflation and unemployment. The present paper therefore aims to fill that gap, examining the impact of zakat distribution on inflation and unemployment, while also revisiting A.W. Phillips' trade-off theory.

\section{Discussion}

\section{The Role of Zakat in Controlling Inflation}

Zakat can control inflation via two analyses: quantitative and qualitative.

Firstly, a quantitative analysis can address natural inflation. This type of inflation occurs due to a mismatch between aggregate demand and aggregate supply. In this context, as a fiscal instrument, zakat plays an important role in income and wealth distribution, stimulating consumption. While governments can allocate zakat funds to all eight eligible recipients (ashnaf) as prescribed by shariah, the poor and needy take priority. From a zakat perspective, the structure of society is divided into three classes: ${ }^{42}$

1. Muzakki, or those with an excess of assets who are obliged to pay zakat. They have a spending pattern as follows:

$\mathrm{FS}=\mathrm{C}-\mathrm{Z}+\mathrm{In}+\mathrm{Sh}+\mathrm{Wq}$

where FS is final spending, C consumption, $\mathrm{Z}$ zakat, In infaq (spending), Sh sadaqah (alms), and Wq waqf.

2. Middle classes, or those who are neither recipients nor payers of zakat. They have spending patterns as follows:

$\mathrm{FS}=\mathrm{C}+\mathrm{In}+\mathrm{Sh}$

3. Mustahiq, or those who are eligible to receive zakat. They have two expenditure patterns:

1. $\mathrm{FS}=\mathrm{Z}$ where $\mathrm{Z}=\mathrm{C}$

2. $\mathrm{FS}=\mathrm{Y}+\mathrm{Z}$ 
where $\mathrm{Z}$ is zakat, $\mathrm{C}$ consumption, and $\mathrm{Y}$ income. The first model signifies consumption that originates entirely from zakat. This category includes faqir, ibnu sabil, and $f$ sabilillah. The second model refers to the poor and needy, or those who have an income, but one that is insufficient to meet their basic needs. In this situation, their final spending exceeds their income level, making them eligible for zakat. ${ }^{43}$

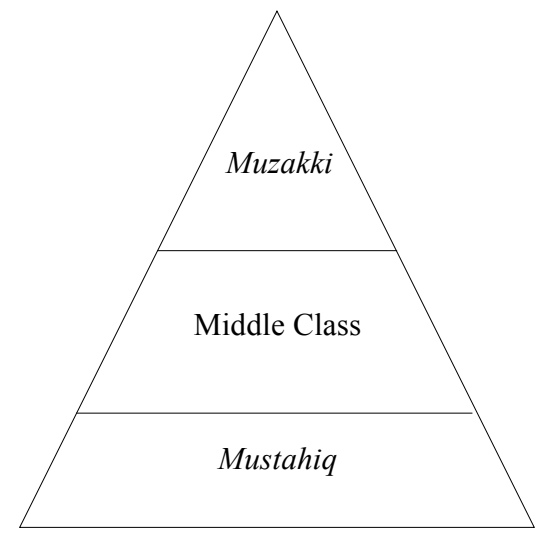

Figure 3: The Structure of Society from a Zakat Perspective

Source: Abu Ubaid's al-Amwal. ${ }^{44}$

It is noteworthy that zakat not only aims to meet the basic needs of the poor, but also strives to enhance their productivity so they can meet their own needs. During the Prophet's lifetime, the distribution of alms therefore took the form not only of consumptive substance, but also productive capital. As a result, a mustahiq can elevate his status to the middle class and, eventually, muzakki. Thus, the above structure is expected to change into Figure 4:

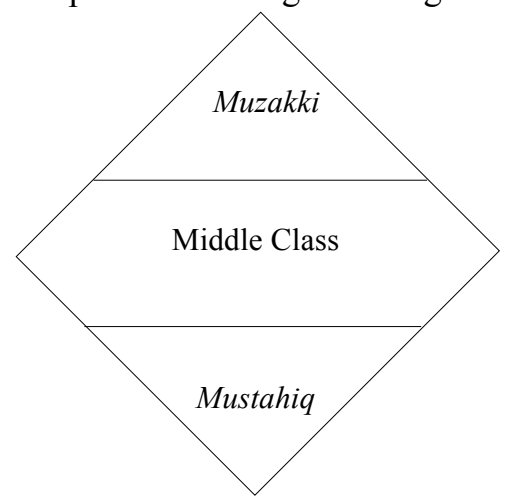

Figure 4: The Ideal Structure of Society from a Zakat Perspective Source: Abu Ubaid's al-Amwal. ${ }^{45}$ 
The distribution of zakat will therefore increase mustahiq income and purchasing power. In other words, according to Metwally, zakat will increase the consumptive power of mustahiq.$^{46}$ The following graph illustrates the impact of zakat on consumption:

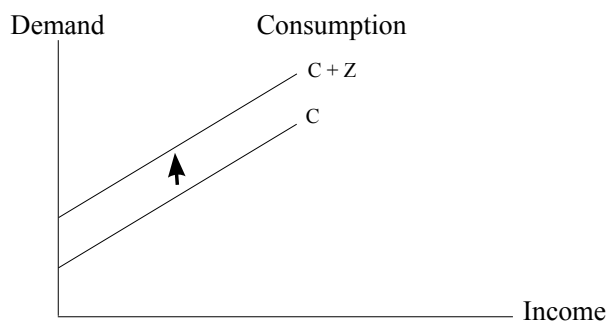

Figure 5: Impact of Zakat on Consumption

Source: Metwally (1992)

The transfer of wealth from the rich to the poor therefore increases the latter's consumption; Line $\mathrm{C}$ of the curve consequently shifts upward to $\mathrm{C}+\mathrm{Z}$ after inclusion of zakat. The distribution of zakat has, therefore, a significant impact on aggregate demand, as illustrated in Figure 6:

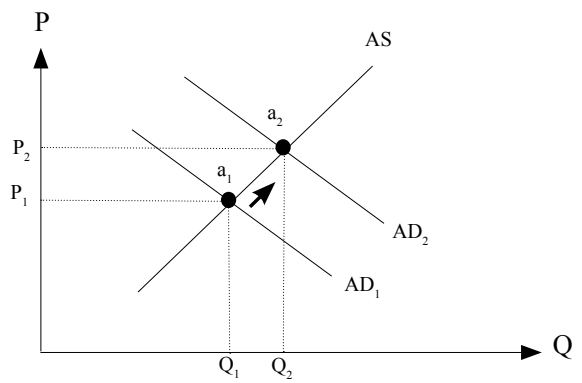

Figure 6: Impact of Zakat on Aggregate Demand

Source: Authors

An increase in income through zakat elevates the level of aggregate demand from $A D_{1}$ to $A D_{2}$, thus shifting the equilibrium from $\mathrm{a}_{1}$ to $\mathrm{a}_{2}$. At a glance, zakat therefore increases the price level from $\mathrm{P}_{1}$ to $\mathrm{P}_{2}$ due to a rise in aggregate demand. However, the distribution of zakat also increases productivity because it is distributed in both consumptive and distributive forms. Therefore, an increase in aggregate demand is concurrently followed by an uptrend in aggregate supply. An increase in aggregate supply will raise the output ( $\mathrm{\uparrow}$ ) and pull the price 
(P) down. This corresponds to the law of demand and supply: the more goods are produced, the lower their price. Conversely, the less goods are produced, the higher their price. The impact of zakat on price stability is depicted in Figure 7:

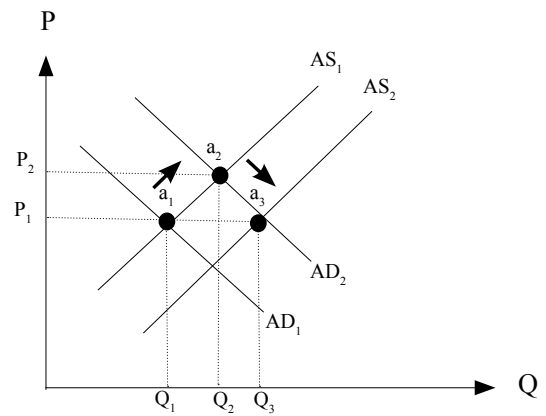

Figure 7: Impact of Zakat on Price Stability Source: Authors

Figure 7 illustrates the effect of zakat on a macro scale. The initial equilibrium (meeting point between AD and AS) is indicated at $\mathrm{a}_{1}$, where the zakat instrument does not function optimally. Under the influence of zakat, the equilibrium point shifts to $\mathrm{a}_{2}$ (where the role of zakat is still not optimal) with the increase of $\mathrm{AD}_{1}$ to $\mathrm{AD}_{2}$. At this point, it appears that prices hike from $\mathrm{P}_{1}$ to $\mathrm{P}_{2}$. However, from the perspective of zakat, a rise in aggregate demand is followed by an increase in aggregate supply. Thus, the rise of aggregate supply from $\mathrm{AS}_{1}$ to $\mathrm{AS}_{2}$ moves the equilibrium point from $\mathrm{a}_{2}$ to $\mathrm{a}_{3}$ (where zakat works optimally). In this final equilibrium, $\mathrm{a}_{3}$ pulls $\mathrm{P}$ down from $\mathrm{P}_{2}$ to $\mathrm{P}_{1}$. From this we can conclude that the optimal application of zakat maintains price stability with an increase in $\mathrm{Q}$ (production quantity) from $\mathrm{Q}_{1}$ to $\mathrm{Q}_{3}$ at the highest level.

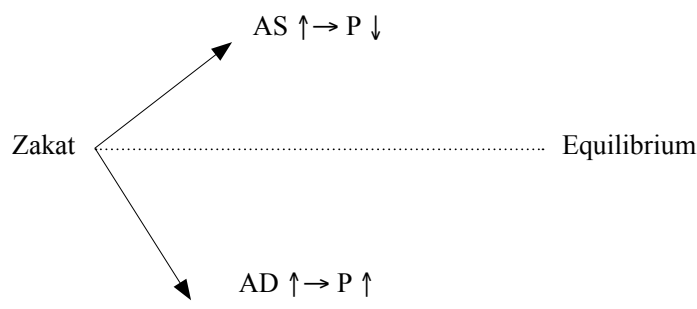

Figure 8: Impact of Zakat on Price Stability

Source: Authors 
Turning to qualitative analysis, this uses a socio-normative approach to overcome inflation due to human factors, such as corruption, poor administration, excessive tax collection, and printing money to generate excessive profits. Zakat plays an important role in overcoming inflation due to human factors based on the following arguments:

1. The collection and distribution of zakat is based on obedience to Allah. This serves as an internal control, avoiding corruption and mismanagement among administrators.

2. Zakat avoids poor administration via its spirit of efficiency, as reflected in the stipulation of a nishab and a clear set of zakat rates.

3. The rate of zakat is stipulated by the Lawgiver. As a result, the use of zakat as a fiscal policy instrument and source of state revenue does not create excessive taxation, which might cause inflation.

4. Printing money to attain profit is not supported by zakat, which stimulates economic growth via productivity and effectiveness.

5. Human error inflation is due to incompetence and lack of integrity. Zakat, on the other hand, encourages skillful human resources, professionalism, and integrity. The state also serves as amil (zakat manager) to manage zakat funds. Important requirements for the amil include competence, professionalism, and high integrity.

\section{The Role of Zakat in Addressing Unemployment}

Unemployment arises when demand for labour is lower than the size of the existing workforce. This might be due to a lack of skilled workers or an economic downturn that shrinks production by creating low demand. Zakat could address the issue of unemployment through the following aspects.

\section{Increased labour supply}

Labour plays a critical role in producing goods and services. Enhancing labour expertise eventually increases labour supply, which in turn increases national output. Figure 9 illustrates the relationship between labour supply and national output: 


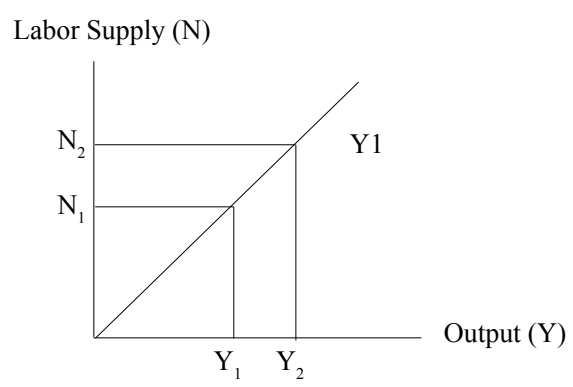

Figure 9: The Relationship between Labour Supply and National Output Source: Sukirno (2000)

This paradigm relates to how assets can be equally distributed, including how zakat can shift the status of mustahiq to muzakki. In this respect, the concept of zakat promotes productivity. For example, self-irrigated agriculture is subject to 5 per cent zakat, while rain-fed agriculture (with no productive activity) is subject to 10 per cent zakat. Additionally, zakat in the Prophet's time and under Caliph 'Umar bin 'Abdul Aziz was not only distributed in the form of basic needs, but also as productive capital. ${ }^{47}$

If the labour supply exceeds demand, increased expertise will eventually recreate demand. This is consistent with the law of Say, which states that supply will create demand. ${ }^{48}$ From the perspective of zakat, increased supply will always be followed by an increase in demand, and vice versa.

\section{Increased labour demand}

As a fiscal policy instrument, zakat could be partly allocated to infrastructure development and social facilities. Some contemporary scholars like al-Qaradawi include this objective under the category of $f i$ sabilillah. Infrastructure development will create new employment and increased national income. This can be analysed using the following mathematical equation:

$\mathrm{Y}_{0}=\frac{1}{1-\mathrm{b}(1-\mathrm{t})}=\left(\mathrm{a}+\mathrm{I}_{0}+\mathrm{G}_{0}\right)$

where $\mathrm{Y}$ is national income, I Investment, and $\mathrm{G}$ government expenditure. Increases in government expenditure $(\Delta \mathrm{G})$ will increase national income to: 
$\mathrm{Y}_{0}=\frac{1}{1-\mathrm{b}(1-\mathrm{t})}=\left(\mathrm{a}+\mathrm{I}_{0}+\mathrm{G}_{0}+\Delta \mathrm{G}\right)$

Increases in real national income $(\Delta \mathrm{Y})$, from as much as $\mathrm{Y} 1-\mathrm{Y} 0=\Delta \mathrm{Y}$, can be calculated as follows:

$$
\mathrm{Y}_{0}=\longleftarrow=\left(\mathrm{a}+\mathrm{I}_{0}+\mathrm{G}_{0}+\Delta \mathrm{G}\right)-\longrightarrow\left(\mathrm{a}+\mathrm{I}_{0}+\mathrm{G}_{0}\right)
$$

Or

$$
\Delta \mathrm{Y}=\begin{gathered}
1 \\
1-\mathrm{b}(1-\mathrm{t})
\end{gathered}
$$

The effect of an increase in government expenditure on fiscal policy can be further explained using the following consumption function curve:

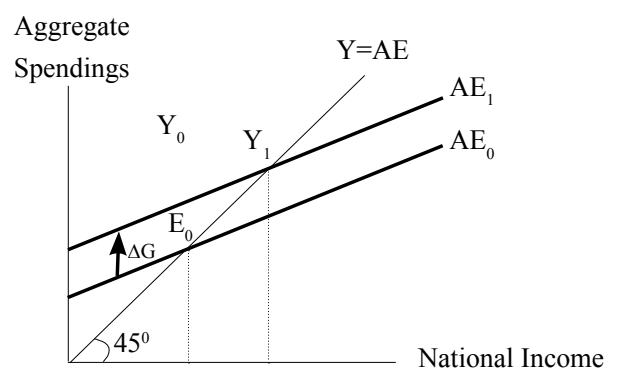

Figure 10: Consumption Function

Source: Sukirno (2000)

As indicated in Figure 10, aggregate expenditure is initially reflected by $\mathrm{AE}_{0}$, with the original equilibrium point at $\mathrm{E}_{0}$ and national income at $\mathrm{Y}_{0}$. An increase in government expenditure of the amount $\Delta \mathrm{G}$ will raise $\mathrm{AE}_{0}$ to $\mathrm{AE}_{1}$. Thus, the new equilibrium point is $\mathrm{E}_{1}$ and the new national income is $\mathrm{Y}_{1}{ }^{49}$

Based on this analysis, zakat expenditure for government infrastructure will increase national output. The national output signifies an increase in productivity that will ultimately increase demand for labour.

\section{Maintaining the balance between labour supply and labour demand.}

As stated earlier, unemployment emerges partly due to an imbalance between labour supply and labour demand. This issue can be overcome by increasing labour demand via incentives to create new jobs. This will reintroduce a 
balance between labour demand and labour supply. To analyse this balance, we use the following labour market graph:

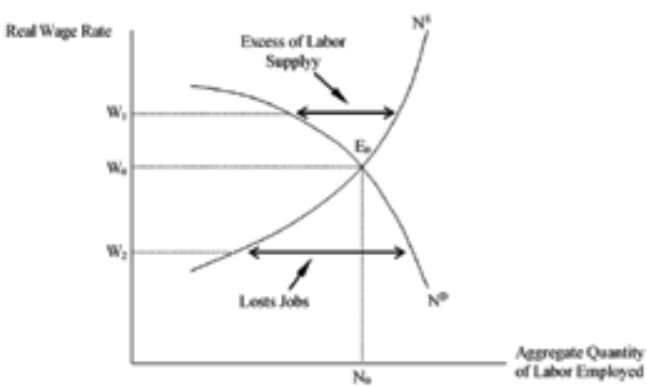

Figure 11: The Aggregate Labour Market and Effect of Minimum Wages Source: Sukirno (2000)

Here, curve $\mathrm{N}^{\mathrm{D}}$ represents labour demand, while $\mathrm{N}^{\mathrm{S}}$ is labour supply. The equilibrium point of the labour market can be realised if labour demand is at par with labour supply. This condition occurs at point $\mathrm{E}_{0}$, where wage rate $=$ $\mathrm{W}_{0}$ and job level $=\mathrm{N}_{0}$. If the wage rate increases to $\mathrm{W}_{1}$, there will be labour oversupply, which means that some of the workforce will be unemployed. According to classical economists, this unemployment will decrease wage rates. This decrease in wage level will then increase labour demand, reducing labour supply. This adjustment process stops if both demand and supply for labour again reach their equilibrium point at $\mathrm{E}_{0}$. Conversely, if the wage rate is at $\mathrm{W}_{2}$, labour demand will rise. This will lead to an increase in wage levels, which in turn leads to an increase in labour supply while reducing labour demand. Eventually, the demand and supply for labour will likewise return to the equilibrium point at $\mathrm{E}_{0} \cdot{ }^{50}$

If we fuse this labour market law with zakat, we find that the latter will always pull conditions to the equilibrium point by increasing both aggregate demand and aggregate supply. This is true since zakat is distributed in two forms: consumptive and productive. The former will increase aggregate demand while the latter raises aggregate supply. High aggregate demand encourages producers to increase their productivity. The higher their productivity, the greater the demand for production factors, including labour. This will pull down $\mathrm{W}_{1}$ to $\mathrm{W}_{0}$. Thus, an excess in labour supply can be minimised. On the other hand, zakat will also push up aggregate supply. This increase in goods and services signifies a rise in production, which in turn increases labour demand. This will pull down $\mathrm{W}_{2}$ to $\mathrm{W}_{0}$ (equilibrium point). 


\section{Revisiting the Trade-off Theory via Zakat}

According to the trade-off theory, unemployment and inflation cannot be solved simultaneously. A country can achieve lower unemployment only if it is willing to face higher inflation rates, and vice versa. This theory is illustrated by the Phillips Curve, as shown in Figure 2 (above). The Phillips Curve illustrates a negative relationship between unemployment and inflation. But, how does this happen? In conventional economics, the Phillips Curve can be rationalised through labour market theory, as follows:

a) Labour Market

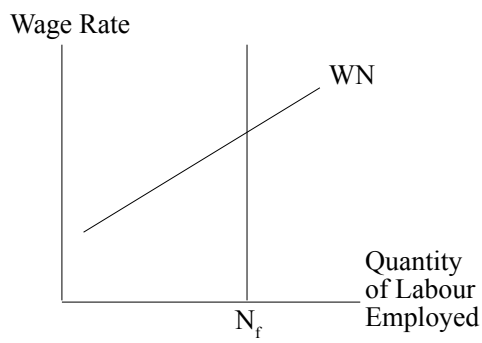

b) Aggregate Supply Curve

General Price Level

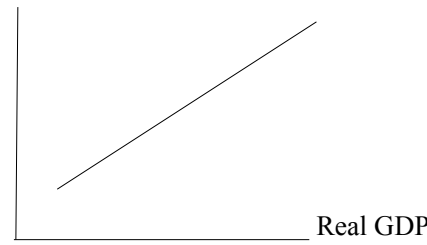

Figure 12: Labour Market and Aggregate Supply Curves

Source: Samuelson (1986) and Jacobsen and Skillman (2004)

The Phillips Curve concludes that the lower the unemployment rate, the higher the increase in wage prices. The WN (wage-employment) curve illustrates the nature of this relationship: the higher the level of employment, the higher the wage level. When this happens, the $\mathrm{N}_{\mathrm{F}}$ in Graph (a) illustrates how increased labour costs makes production more expensive. As companies are established to make profit, higher production costs will force an increase in the price of goods, which in turn effects real GDP. In other words, if employment opportunities increase, real national production also increases, which inflates wages. A rise in wages increases production costs, which in turn raises the price of goods, as illustrated in Graph (b). ${ }^{51}$

The response to this situation is as follows: if an increase in wages also increases price levels, this signifies that, although the nominal income of workers is higher, their real income is not. This is particularly true if the increase in nominal wage is smaller than the rate of inflation. In an Islamic economy, when zakat is implemented optimally, this situation should not exist because an increase in productivity follows an increase in wages. This conclusion is further substantiated by productivity analysis, where price $(\mathrm{P})$ is a function of total cost 
(TC) divided by total production (Q), as follows:

$$
\mathrm{P}=\frac{\mathrm{TC}}{\mathrm{Q}}
$$

If TC increases without a rise in $\mathrm{Q}, \mathrm{P}$ will inflate. However, since under zakat an increase in $\mathrm{Q}$ follows a rise in TC, $\mathrm{P}$ remains stable. This increase in $\mathrm{Q}$ is the ultimate objective of zakat. An increase in Q via zakat will be due either to cost efficiency or improved labour expertise, thus increasing productivity. Additionally, Q will reach its optimal point because it is followed by an increase in aggregate demand. This indicates an increase in real wages, reflecting better welfare.

Furthermore, because price levels are associated with aggregate goods and services, we can employ Irving Fisher's assumption that $M V=P Q=Y$, where $M$ is money supply, $\mathrm{V}$ the speed of money circulation, $\mathrm{P}$ price level, $\mathrm{Q}$ the quantity of goods and services, and Y real GDP. Based on this equation, we can conclude that $\mathrm{P}$ will not rise when $\mathrm{Q}$ increases. This is because $\mathrm{M}$ also rises, while $\mathrm{V}$ remains unchanged..$^{52}$

On the other hand, the Phillips Curve says that decreased unemployment will increase income. An increase in income will increase aggregate demand, thus creating inflation. Figure 13 illustrates the impact of aggregate demand on inflation:

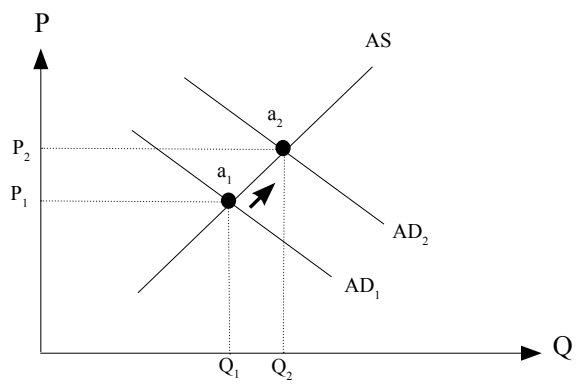

Figure 13: Impact of Aggregate Demand on Inflation

Source: Authors

As discussed, zakat can resolve inflation due to an increase in aggregate demand. This is because the distribution of zakat raises aggregate demand while also pushing up aggregate supply. The distribution of zakat in a consumptive form will raise aggregate demand, while the allocation of zakat as productive capital 
will boost aggregate supply. A rise in both aggregate demand and aggregate supply will establish an equilibrium point, rendering price levels stable. In other words, when the implementation of zakat is optimal, prices remain stable and Q (production quantities) shifts from $\mathrm{Q}_{1}$ to $\mathrm{Q}_{3}$ at its highest equilibrium point, as illustrated in Figure 14:

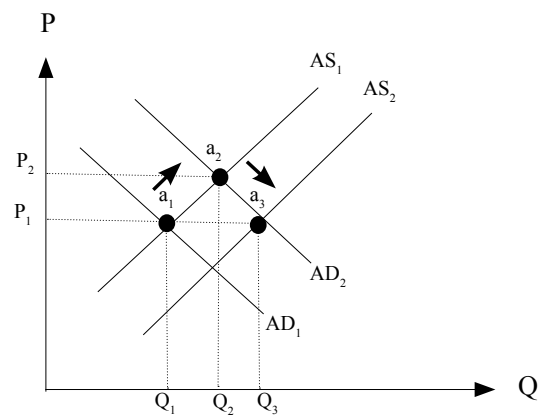

Figure 14: Impact of Zakat on Inflation

Source: Authors

Based on the above analysis, we can conclude that zakat could become the anti-thesis of Phillips' trade-off theory, with the optimal distribution of zakat overcoming both unemployment and inflation simultaneously.

\section{Conclusion and Recommendations}

Inflation and unemployment are the two main problems facing both developed and developing countries. On the basis of A. W. Phillips' work linking these two issues, conventional economic theory argues that these two problems cannot be solved concurrently.

This paper has argued that zakat could serve as the anti-thesis to Phillips' trade-off theory. The optimal distribution of zakat could resolve both inflation and unemployment by addressing the latter via increases in both labour supply and demand, while also maintaining a balance between these two things. Zakat can also control natural inflation because it is distributed in both consumptive and distributive forms, meaning an increase in aggregate supply will be followed by a rise in aggregate demand. An increase in aggregate supply raises output $(\mathrm{Q}$ $\uparrow)$ and pulls prices (P) down. In addition, zakat addresses inflation due to human factors because it is based on obedience to Allah and efficiency. The system also stimulates economic growth by inspiring productivity and effectiveness. It also 
encourages skillful human resources, professionalism, and integrity.

To assist zakat in addressing the above issues, the paper recommends the following:

1. Zakat be managed by the state as an integral instrument of fiscal policy.

2. Zakat be obligatory. In this respect, zakat should be administered by a dedicated ministry as a deductible variable for tax.

3. Zakat institutions be managed by qualified, professional, and accountable 'amil for effective functioning.

4. Zakat institutions need to explore the possibility of allocating zakat funds for productive purposes and job creation. For example, a portion of zakat should be designated for development, especially in disadvantaged or remote areas. This will eventually open up more employment opportunities.

\section{Notes}

* Mohammad Syafii Antonio, Chairman of Tazkia Islamic University College, Indonesia. He can be contacted at: msantonio@tazkia.ac.id.

** Mohammad Mahbubi Ali, Associate Fellow and Head of the Economics, Finance, Awqaf and Zakat division at IAIS Malaysia. He is also a lecturer at Tazkia Islamic University College, Indonesia. He can be contacted at: mahbubi@iais.org.my.

*** Jebel Firdaus, Masters Student at Tazkia Islamic University College, Indonesia. He can be contacted at: maulaya11@gmail.com.

1. Richard G. Lipsey and Colin Harbury, First Principles of Economics (New York: Oxford University Press, 2004).

2. A. W. Phillips, 'The Relation Between Unemployment and The Rate of Change of Money Wage Rates in The United Kingdom, 1861-1957,' Economica 25, no. 100 (1958): 283-99.

3. Ibid., 283.

4. M. Ramesh, 'Economic Crisis and Its Social Impacts,' Global Social Policy 9, no. 1 (2009): 79-99.

5. Obaidullah and Shirazi, Islamic Social Finance Report 1436H/2015 (Jeddah: IRTI IDB, 2015).

6. World Bank and Islamic Development Bank Group, Global Report on Islamic Finance: Islamic Finance: A Catalyst for Shared Prosperity (Washington, DC: World Bank, 2016).

7. Adel Sarea, 'Zakat as a Benchmark to Evaluate Economic Growth: An Alternative Approach,' International Journal of Business and Social Science 3, 
no.18 (2012): 242-5; Mohammed B. Yusoff, 'Zakat Distribution and Growth in The Federal Territory of Malaysia,' Journal of Economics and Behavioral Studies 4, no. 8 (2012): 449-56; Muhammad Azam, Nasir Iqbal and Muhammad Tayyab, 'Zakat and Economic Development: Micro and Macro Level Evidence from Pakistan,' Bulletin of Business and Economics 3, no. 2 (2014): 85-95; Mohammed B. Yusoff, 'Zakat Expenditure, School Enrollment, and Economic Growth in Malaysia,' International Journal of Business and Social Science 2, no. 6 (2011): 175-81; Bilal Ahmad Malik, 'Philanthropy in Practice: Role of Zakat in the Realization of Justice and Economic Growth,' International Journal of Zakat 1, no. 1 (2016); 64-77; Nor Idayu Mahat and Ari Warokka, 'Investigation on Zakat as an Indicator for Moslem Countries' Economic Growth,' Journal for Global Business Advancement 6, no. 1 (2013): 50-8.

8. M. Kabir Hassan and A. Ashraf, 'An Integrated Poverty Alleviation Model Combining Zakat, Awqaf and Micro-Finance,' in Seventh International Conference-The Tawhidic Epistemology: Zakat and Waqf Economy, Bangi, Malaysia (2010): 261-81; M. Kabir Hassan and Juanyed Masrur Khan, 'Zakat, External Debt and Poverty Reduction Strategy in Bangladesh,' Journal of Economic Cooperation Among Islamic Countries 28, no. 4 (2007): 1-38; Farah Aida Ahmad Nadzri, Rashidah Abd Rahman and Normah Omar, 'Zakat and Poverty Alleviation: Roles of Zakat Institutions in Malaysia,' International Journal of Arts and Commerce 1, no. 7 (2012): 61-72; Nasim Shah Shirazi, 'Integrating Zakat and Waqf into the Poverty Reduction Strategy of The IDB Member Countries,' Islamic Economic Studies 130, no. 1155 (2014): 1-30; Lukman Raimi, Ashok Patel and Ismail Adelopo, 'Corporate Social Responsibility, Waqf System and Zakat System as Faith-Based Model for Poverty Reduction,' World Journal of Entrepreneurship, Management and Sustainable Development 10, no. 3 (2014): 228-42; Mohd Rodzi Embong, Roshaiza Taha and Mohd Nazli Mohd Nor, 'Role of Zakat to Eradicate Poverty in Malaysia,' Jurnal Pengurusan (UKM Journal of Management) 39 (2013): 141-50; Isahaque Ali and Zulkarnain A. Hatta, 'Zakat as a Poverty Reduction Mechanism among the Muslim Community: Case Study of Bangladesh, Malaysia, and Indonesia,' Asian Social Work and Policy Review 8, no. 1 (2014): 59-70.

9. Muhammad Zulfiqar, Zakat according to the Quran and Sunnah (Riyadh: Maktaba Dar al-Salam, 2011).

10. Norazlina Abd Wahab and Abdul Rahim Abdul Rahman, 'A Framework to Analyse the Efficiency and Governance of Zakat Institutions,' Journal of Islamic Accounting and Business Research 2, no.1 (2011): 43-62.

11. Hukmiah Husain, Nasir Hamzah, Ambo Asse and Muslimim Kara, 'Yusuf AlQaradawi Concept on Professional Zakat,' International Journal of Multicultural and Multireligious Understanding 6, no. 6 (2019): 1-9.

12. Qur'an, 9:60

13. D.N. Dwivedi, Macroeconomics Theory and Policy, $3^{\text {rd }}$ ed. (New Delhi: Tata McGraw Hill Education, 2010), 453-6.

14. Ibid.

15. Ascarya, 'The Determinants of Inflation under Dual Monetary System in Indonesia,' Working Paper Bank Indonesia, (2009).

16. Frotz Machlup, 'Another View of Cost-Push and Demand-Pull Inflation,' The 
Review of Economics and Statistics 42, no. 2 (1960): 125-39.

17. Ascarya 'The Determinants of Inflation.'

18. Al-Maqrizi, Ighathah al-Ummah Bi Kashf al-Ghummah (Riyadh: Maktabah alUsrah, 1999).

19. Ibid.

20. Adiwarman Karim, Ekonomi Islam: Suatu Kajian Ekonomi Makro (Jakarta: The International Institute of Islamic Thought, 2002).

21. Adiwarman Karim, Sejarah Pemikiran Ekonomi Islam (Jakarta: Rajawali Pers., 2004).

22. Sukirno, Makroekonomi Modern (Jakarta: Raja Grafindo Persada, 2000).

23. Phillips, 'Relation between Unemployment,' 283.

24. Johannes A. Schwarzer, 'Samuelson and Solow on the Phillips curve and the "Menu of Choice": a Retrospective,' Economia: History, Methodology, Philosophy 3, no. 3 (2013): 359-88.

25. Paul A. Samuelson and William D. Nordhaus, Ekonomi (Jakarta: Erlangga, 1986).

26. Sarea, 'Zakat as a Benchmark'; Yusoff, 'Zakat Expenditure'; Azam et al., 'Zakat and Economic Development'; Yusoff, 'Zakat Distribution and Growth'; Elleriz Aisha Khasandy and Rudy Badrudin, 'The Influence of Zakat on Economic Growth and Welfare Society in Indonesia,' Integrated Journal of Business and Economics 3, no. 1 (2019): 65-79; Mahat and Warokka, 'Investigation on Zakat.'

27. Sarea, 'Zakat as a Benchmark.'

28. Mahat and Warokka, 'Investigation on Zakat,' 50-8.

29. Yusoff, 'Zakat Expenditure,' 175-81.

30. Azam, Iqbal and Tayyab, 'Zakat and Economic Development,' 85-95.

31. Khasandy et al., 'Influence of Zakat on Economic Growth.'

32. Hassan and Ashraf, 'Integrated Poverty Alleviation Model,'; Shirazi et al., 'Integrating Zakat and Waqf,'; Raimi et al., 'Corporate Social Responsibility,'; Embong et al., 'Role of Zakat to Eradicate Poverty,'; Ali and Hatta, 'Zakat as a Poverty Reduction Mechanism,'; Mohamad Soleh Nurzaman, Zakat and Human Development: An Empirical Analysis on Poverty Alleviation in Jakarta, Indonesia (Doha: Center for Islamic Economics and Finance, Qatar Faculty of Islamic Studies, Qatar Foundation, 2010), 1-26.

33. Qur'an 59:7

34. Qur'an 9:60

35. Al-Qaradhawi, Spektrum Zakat, trans. Sari Narulita (Jakarta: Zikrul Hakim, 2005).

36. M. M. Metwally, 'Fiscal Policy in an Islamic Economy,' in Fiscal Policy and Resource Allocation in Islam, ed. Ziauddin Ahmed, Munawar Iqbal, and M. Fahim Khan (Islamabad: Institute of Policy Studies, 1983), 59-81.

37. Naziruddin Abdullah, A. Mat Derus and Husam-Aldin al-Malkawi, 'The Effectiveness of Zakat in Alleviating Poverty and Inequalities: A Measurement Using a Newly Developed Technique,' Humanomics 31, no. 3 (2015): 314-29.

38. Raimi et al., 'Corporate Social Responsibility,' 228-42.

39. Eman Ahmed Hashem and Shaimaa El-sha'er, 'Can Zakah Help to Enhance Financial Inclusion? Case Study Egypt,' International Journal of Education and Research 3, no. 3 (2015): 413-32. 
40. Salman Ahmed Shaikh and Abdul Ghafar Ismail, 'Role of Zakat in Sustainable Development Goals,' International Journal of Zakat 2, no. 2 (2017): 1-9.

41. Zainulbahar Noor and Francine Pickup, The Role of Zakat in Supporting the Sustainable Development Goals (Jakarta: Baznas-UNDP, 2017).

42. Karim, Ekonomi Islam.

43. Ibid.

44. Abu Ubaid, Kitab al Amwal (Beirut: Dar al Fikr, 1988).

45. Ibid.

46. Metwally, 'A Behavioural Model of an Islamic Firm,' in Readings in Macroeconomics: An Islamic Perspective, ed. Sayyid Tahir and Aidit Ghazali (Longman Malaysia: Kuala Lumpur, 1992).

47. Abdul Hamid Mahmud, Ekonomi Zakat: Sebuah Kajian Moneter dan Keuangan Syariah (Jakarta: Raja Grafindo Persada, 2006).

48. Steven Kates, "'Supply Creates its Own Demand": A Discussion of the Origins of the Phrase and of its Adequacy as an Interpretation of Say's Law of Markets,' History of Economics Review 41, no.1 (2005): 49-60.

49. Sukirno, Makroekonomi Modern.

50. Ibid.

51. Samuelson and William, Ekonomi.

52. Sukirno, Makroekonomi Modern.

\section{Bibliography}

Abd Wahab, N. and Abdul Rahman, A. R. 'A Framework to Analyse the Efficiency and Governance of Zakat Institutions.' Journal of Islamic Accounting and Business Research 2, no.1 (2011): 43-62.

Abdullah, N., Mat Derus, A. and al-Malkawi, H. 'The Effectiveness of Zakat in Alleviating Poverty and Inequalities: A Measurement Using a Newly Developed Technique.' Humanomics 31, no. 3 (2015): 314-29.

Abu Ubaid. Kitab al Amwal. Beirut: Dar al Fikr, 1988.

Al-Maqrizi. Ighathah al-Ummah Bi Kashf al-Ghummah. Riyadh: Maktabah alUsrah, 1999.

Ali, I. and Hatta, Z. A. 'Zakat as a Poverty Reduction Mechanism among the Muslim Community: Case Study of Bangladesh, Malaysia, and Indonesia.' Asian Social Work and Policy Review 8, no. 1 (2014): 59-70.

Al-Qaradhawi. Spektrum Zakat. Translated by Sari Narulita. Jakarta: Zikrul Hakim, 2005.

Ascarya. 'The Determinants of Inflation under Dual Monetary System in Indonesia.' Working Paper Bank Indonesia, 2009.

Azam, M., Iqbal, N., and Tayyab, M. 'Zakat and Economic Development: Micro and Macro Level Evidence from Pakistan.' Bulletin of Business and Economics 3, no. 2 (2014): 85-95. 
Dwivedi, D.N. Macroeconomics Theory and Policy, $3^{\text {rd }}$ Edition. New Delhi: Tata McGraw Hill Education, 2010.

Embong, M. R., Taha R. and Mohd Nor, M. N. 'Role of Zakat to Eradicate Poverty in Malaysia.' Jurnal Pengurusan (UKM Journal of Management) 39 (2013): 14150.

Hashem, E. A. and El-sha'er, S. 'Can Zakah Help to Enhance Financial Inclusion? Case Study Egypt.' International Journal of Education and Research 3, no.3 (2015): 413-32.

Hassan, M. K. and Ashraf A. 'An Integrated Poverty Alleviation Model Combining Zakat, Awqaf and Micro-Finance.' In Seventh International Conference-The Tawhidic Epistemology: Zakat and Waqf Economy, Bangi, Malaysia (2010): 261-81.

Hassan, M. K. and Khan, J. M. 'Zakat, External Debt and Poverty Reduction Strategy in Bangladesh.' Journal of Economic Cooperation Among Islamic Countries 28, no. 4 (2007): 1-38.

Husain, H., Hamzah, N., Asse, A. and Kara, M. 'Yusuf Al-Qaradawi Concept on Professional Zakat.' International Journal of Multicultural and Multireligious Understanding 6, no. 6 (2019): 1-9.

Karim, A. Ekonomi Islam: Suatu Kajian Ekonomi Makro. Jakarta: The International Institute of Islamic Thought (IIIT), 2002.

—. Sejarah Pemikiran Ekonomi Islam. Jakarta: Rajawali Pers., 2004.

Kates, S. "“Supply Creates its Own Demand": A Discussion of the Origins of the Phrase and of its Adequacy as an Interpretation of Say's Law of Markets.' History of Economics Review 41, no.1 (2005): 49-60.

Khasandy, E. A. and Badrudin, R. 'The Influence of Zakat on Economic Growth and Welfare Society in Indonesia.' Integrated Journal of Business and Economics 3, no. 1 (2019): 65-79.

Lipsey, Richard G. and Harbury, C. First Principles of Economics. New York: Oxford University Press, 2004.

Machlup, F. 'Another View of Cost-Push and Demand-Pull Inflation.' The Review of Economics and Statistics 42, no. 2 (1960): 125-39.

Mahat. N. I. and Warokka, A. 'Investigation on Zakat as an Indicator for Moslem Countries' Economic Growth.' Journal for Global Business Advancement 6, no. 1 (2013): 50-8.

Mahmud, A. H. Ekonomi Zakat: Sebuah Kajian Moneter dan Keuangan Syariah. Jakarta: Raja Grafindo Persada, 2006.

Malik, B. A. 'Philanthropy in Practice: Role of Zakat in the Realization of Justice and Economic Growth.' International Journal of Zakat 1, no. 1 (2016); 64-77.

Metwally, M. M. 'A Behavioural Model of an Islamic Firm.' In Readings in 
Macroeconomics: An Islamic Perspective, edited by Sayyid Tahir and Aidit Ghazali. Longman Malaysia: Kuala Lumpur, 1992.

Metwally, M. M. 'Fiscal Policy in an Islamic Economy.' In Fiscal Policy and Resource Allocation in Islam, edited by Ziauddin Ahmed, Munawar Iqbal, and M. Fahim Khan, 59-81. Islamabad: Institute of Policy Studies, 1983.

Nadzri, F. A. A., Abd Rahman, R. and Omar, N. 'Zakat and Poverty Alleviation: Roles of Zakat Institutions in Malaysia.' International Journal of Arts and Commerce 1, no.7 (2012): 61-72.

Noor, Z. and Pickup, F. The Role of Zakat in Supporting the Sustainable Development Goals. Jakarta: Baznas-UNDP, 2017.

Nurzaman, M. S. Zakat and Human Development: An Empirical Analysis on Poverty Alleviation in Jakarta, Indonesia. Doha: Center for Islamic Economics and Finance, Qatar Faculty of Islamic Studies, Qatar Foundation, 2010.

Obaidullah and Shirazi. Islamic Social Finance Report 1436H/2015. Jeddah: IRTI IDB, 2015.

Phillips, A. W. 'The Relation Between Unemployment and The Rate of Change of Money Wage Rates in The United Kingdom, 1861-1957.' Economica 25, no. 100 (1958): 283-99.

Raimi, L., Patel, A. and Adelopo, I. 'Corporate Social Responsibility, Waqf System and Zakat System as Faith-Based Model for Poverty Reduction.' World Journal of Entrepreneurship, Management and Sustainable Development 10, no. 3 (2014): 228-42.

Ramesh, M. 'Economic Crisis and Its Social Impacts.' Global Social Policy 9, no.1 (2009): 79-99.

Samuelson, P. A. and Nordhaus, W. D. Ekonomi. Jakarta: Erlangga, 1986.

Sarea, A. 'Zakat as a Benchmark to Evaluate Economic Growth: An Alternative Approach.' International Journal of Business and Social Science 3, no. 18 (2012): 242-5.

Schwarzer, J. A. 'Samuelson and Solow on the Phillips curve and the "Menu of Choice": A Retrospective.' Economia: History, Methodology, Philosophy 3, no. 3 (2013): 359-88.

Shaikh, S. A. and Ismail, A. G. 'Role of Zakat in Sustainable Development Goals.' International Journal of Zakat 2, no. 2 (2017): 1-9.

Shirazi, N. S. 'Integrating Zakat and Waqf into the Poverty Reduction Strategy of The IDB Member Countries.' Islamic Economic Studies 130, no. 1155 (2014): 1-30.

Sukirno. Makroekonomi Modern. Jakarta: Raja Grafindo Persada, 2000.

World Bank and Islamic Development Bank Group. Global Report on Islamic Finance: Islamic Finance: A Catalyst for Shared Prosperity. Washington, DC: World Bank, 2016. 
Yusoff, M. B. 'Zakat Distribution and Growth in The Federal Territory of Malaysia.' Journal of Economics and Behavioral Studies 4, no. 8 (2012): 449-56.

. 'Zakat Expenditure, School Enrollment, and Economic Growth in Malaysia.' International Journal of Business and Social Science 2, no. 36 (2011): 175-81.

Zulfiqar, M. Zakat According to the Quran \& Sunnah. Riyadh: Maktaba Dar alSalam, 2011. 